\title{
Comparison of different stoichiometric methods for the estimation of proximate biochemical composition of crustacean zooplankton and some considerations on energy transfer to planktophagous fish
}

\author{
Nicoletta RICCARDI \\ CNR Istituto Italiano di Idrobiologia, Largo Tonolli 50, I-28922 Verbania Pallanza, Italy
}

In a previous publication (Riccardi \& Mangoni 1999) the proximate biochemical composition of some freshwater zooplankton species was estimated from $\mathrm{C}$, $\mathrm{H}$ and $\mathrm{N}$ content by a calculation method developed by Gnaiger \& Bitterlich (1984). The stoichiometric coefficients used by these authors to calculate protein, lipid and carbohydrate fractions were based on reference compounds specifically selected to represent the composition of the soft tissues of fish and molluscs. According to Vollenweider (2000, this issue) the application of Gnaiger \& Bitterlich's equations in estimating zooplankton proximate composition could lead to erroneous estimates, mainly resulting from the fact that carbohydrate is primarily present in the form of chitin. The discussion arising from this question led Dr. Vollenweider to develop a modified calculation procedure and to explore the reliability and the confidence limits of proxy estimates.

The answer to the fundamental question of how reliable proxy estimates are depends both on the choice of reference compounds representative of sample composition and on the precision and confidence of the input data. Any error in $\mathrm{CHN}$ measurements, and particularly in the hydrogen fraction, is amplified by the calculation procedure, leading to biased estimates. Uncertainty of hydrogen measurements is generally higher than that of carbon and nitrogen measurements, mainly because of dry matter rehydratation during sample handling and analysis.

To avoid, or at least minimize, this source of error, we followed the methodological procedure for $\mathrm{CHN}$ analysis suggested by Gnaiger \& Bitterlich (1985). According to this procedure dried samples must be redried after each manipulation (weight determination, homogenization), sealed into tin caps, redried and stored in a desiccator over silica gel until CHN analysis. During the operation of the elemental analyzer the sample tray must be covered by an airtight Perspex box containing silica gel.

Analyses were carried out on triplicate subsamples for both dry matter and ashes. When the amount of sample was too low, only duplicate analyses were performed. The residual water content calculated by the Gnaiger \& Bitterlich equations was used to evaluate which samples had suffered by rehydratation, thus allowing the exclusion of the relative data from the fol- lowing calculations. In the remaining samples the average residual water content amounted to $0.05 \pm 0.02$.

The variability of replicate analyses of subsamples was in the same range as that measured on multiple samples collected at the same time and site, while samples collected in different seasons and sites showed only a slightly higher variability. The data summarized in table 1 represent the mean, STD and $\mathrm{cv}$ (STD/mean) values calculated for samples of the same species collected at the same time and in the same site (A) compared to those calculated on the whole pool of samples collected during different seasons in different lakes (B). It is evident that nitrogen and hydrogen values are characterized by a higher variability than carbon values, with $\mathrm{cv}$ values ranging from 0.01 to 0.10 and 0.01 to 0.08 respectively. As Vollenweider clearly demonstrates, even a cvH $=0.025$ is not sufficient to allow the $\mathrm{CH}$ estimates to assume some consistency.

The effect of element measurements variability on proxy estimates obtained by stoichiometric models was already evident from the values reported by Riccardi \& Mangoni (1999, Tab. 2). Aware of this large degree of uncertainty, we pooled the data and presented them as mean values for each species in the different lakes.

As Vollenweider proposes, two paths can be followed. Either the number of replicate samples or replicate measurements per sample can be increased to obtain a more reliable mean, or a lower level of confidence can be accepted, whichever is possible. Unfortunately, it is frequently difficult to use the first approach, at least when working with zooplankton samples collected in the field. There are obvious practical problems, such as the necessity of obtaining "pure" samples (one species or developmental stage) composed of a sufficient number of live individuals to allow CHN analyses of both dry matter and ashes. In numerical terms this means about 500 individuals for adults of the medium/large species (e.g. Daphnia cucullata, D. hyalina and Cyclops abyssorum) but up to several thousand individuals for naupliar stages of copepods or small species.

On the other hand, as Vollenweider recognises, the acceptable confidence level cannot be reduced below a certain limit without running the risk of obtaining nonsensical numbers.

Any improvement in analytical methods, either to increase precision or to reduce the amount of sample re- 
Tab. 1. Mean, standard deviation (STD) and coefficient of variation ( $\mathrm{cv}=\mathrm{STD} / \mathrm{mean}$ ) calculated for samples of the same species collected at the same time and at the same site (A) compared to those calculated on the whole pool of samples collected during different seasons in different lakes (B).

\begin{tabular}{|c|c|c|c|c|c|c|c|c|c|c|c|c|}
\hline \multirow[b]{2}{*}{ species } & \multirow[b]{2}{*}{ lake } & \multirow[b]{2}{*}{ date } & \multirow[b]{2}{*}{ No. } & \multicolumn{3}{|c|}{ carbon } & \multicolumn{3}{|c|}{ nitrogen } & \multicolumn{3}{|c|}{ hydrogen } \\
\hline & & & & Mean & STD & $\mathrm{cv}$ & Mean & STD & $\mathrm{cv}$ & Mean & STD & $\mathrm{cv}$ \\
\hline Daphnia hyalina & $\mathrm{MO}$ & 28 March & 4 & 52.71 & 1.36 & 0.03 & 11.15 & 0.83 & 0.07 & 7.68 & 0.20 & 0.03 \\
\hline Daphnia cucullata & $\mathrm{CO}$ & $16 \mathrm{March}$ & 3 & 55.57 & 0.35 & 0.01 & 10.36 & 0.08 & 0.01 & 8.08 & 0.05 & 0.01 \\
\hline Aaphnia cucullata & $\mathrm{CO}$ & 11 July & 4 & 50.47 & 2.58 & 0.05 & 9.32 & 0.97 & 0.10 & 7.40 & 0.59 & 0.08 \\
\hline${ }^{\mathrm{A}}$ Cyclops abyssorum (nauplia) & $\mathrm{CO}$ & 14 March & 4 & 51.00 & 1.45 & 0.03 & 11.68 & 1.02 & 0.09 & 7.64 & 0.32 & 0.04 \\
\hline Cyclops abyssorum (adults) & VA & 22 March & 4 & 53.98 & 1.60 & 0.03 & 11.52 & 0.52 & 0.04 & 8.06 & 0.30 & 0.04 \\
\hline Daphnia hyalina & $\mathrm{MO}, \mathrm{MA}$ & & 11 & 51.92 & 2.63 & 0.05 & 10.98 & 0.68 & 0.06 & 7.64 & 0.3 & 0.05 \\
\hline Daphnia cucullata & $\mathrm{CO}, \mathrm{VA}$ & & 16 & 53.62 & 3.09 & 0.06 & 10.34 & 0.91 & 0.09 & 7.83 & 0.53 & 0.07 \\
\hline $\begin{array}{l}\text { Cyclops abyssorum (nauplia, } \\
\text { copepodites, adults) }\end{array}$ & $\mathrm{CO}, \mathrm{VA}, \mathrm{MO}$ & & 27 & 53.24 & 2.16 & 0.04 & 11.19 & 1.02 & 0.09 & 7.80 & 0.37 & 0.05 \\
\hline Eudiaptomus padanus & $\mathrm{CO}, \mathrm{MA}, \mathrm{MO}$ & & 13 & 53.23 & 3.34 & 0.06 & 9.48 & 1.49 & 0.16 & 7.84 & 0.47 & 0.06 \\
\hline All samples & & & 67 & 52.75 & 1.47 & 0.04 & 10.81 & 0.68 & 0.08 & 7.77 & 0.29 & 0.05 \\
\hline
\end{tabular}

Tab. 2. Mean proximate composition ( $\%$ ash free dry weight) of zooplankton species calculated according to Gnaiger \& Bitterlich's (1984) and Vollenwider's (2000) procedures. Lakes: $\mathrm{Co}=$ Comabbio; $\mathrm{Ma}=$ Maggiore; $\mathrm{Mo}=$ Monate and Va $=$ Varese. No. $=$ number of samples.

\begin{tabular}{|c|c|c|c|c|c|c|c|c|}
\hline \multirow[b]{2}{*}{ Species } & \multirow[b]{2}{*}{ lake } & \multirow[b]{2}{*}{ No. } & \multicolumn{3}{|c|}{ Gnaiger \& Bitterlich, 1984} & \multicolumn{3}{|c|}{ Vollenweider, 2000} \\
\hline & & & $\%$ LP & $\% \mathrm{CH}$ & $\% \mathrm{PR}$ & $\%$ LP & $\% \mathrm{CH}$ & $\% \mathrm{PR}$ \\
\hline \multirow[t]{2}{*}{ Daphnia cucullata } & Co & 11 & $19.84 \pm 11.12$ & $22.91 \pm 14.24$ & $57.25 \pm 4.90$ & $20.39 \pm 9.62$ & $31.26 \pm 18.84$ & $48.35 \pm 11.26$ \\
\hline & $\mathrm{Va}$ & 4 & $22.69 \pm 4.87$ & $14.55 \pm 8.23$ & $62.76 \pm 4.20$ & $20.92 \pm 4.57$ & $20.56 \pm 13.75$ & $58.52 \pm 9.80$ \\
\hline \multirow[t]{2}{*}{ Daphnia hyalina } & Mo & 8 & $14.54 \pm 5.14$ & $23.63 \pm 7.62$ & $61.83 \pm 3.71$ & $12.88 \pm 4.99$ & $35.57 \pm 12.82$ & $51.55 \pm 8.84$ \\
\hline & $\mathrm{Ma}$ & 2 & 13.07 & 22.88 & 64.04 & 11.12 & 35.03 & 53.85 \\
\hline Ceriodaphnia quadrangula & $\mathrm{Co}$ & 1 & 5.29 & 40.31 & 54.41 & 4.56 & 62.89 & 32.55 \\
\hline Bythotrephes longimanus & $\mathrm{Ma}$ & 1 & 14.12 & 22.04 & 63.85 & 12.30 & 33.41 & 54.28 \\
\hline Eudiaptomus padanus & Co & 7 & $26.93 \pm 11.52$ & $22.91 \pm 3.90$ & $50.15 \pm 8.55$ & $23.70 \pm 11.62$ & $37.03 \pm 8.07$ & $39.27 \pm 7.92$ \\
\hline \multirow{2}{*}{ (adults + copepodites) } & Mo & 4 & $17.00 \pm 3.81$ & $29.04 \pm 5.82$ & $53.95 \pm 3.41$ & $15.92 \pm 3.69$ & $44.63 \pm 9.77$ & $39.65 \pm 6.93$ \\
\hline & $\mathrm{Ma}$ & 2 & 16.37 & 19.97 & 63.66 & 14.57 & 29.83 & 55.60 \\
\hline \multicolumn{9}{|l|}{ Cyclops abyssorum } \\
\hline copepodites & & 2 & 19.63 & 18.21 & 62.16 & 19.00 & 32.10 & 48.91 \\
\hline adults & Co & 5 & $13.90 \pm 5.89$ & $19.77 \pm 4.08$ & $66.33 \pm 2.00$ & $13.87 \pm 5.69$ & $34.19 \pm 6.57$ & $51.94 \pm 1.34$ \\
\hline ovigerous females & & 2 & 34.57 & 11.17 & 54.26 & 33.86 & 20.63 & 45.51 \\
\hline nauplia & & 1 & 19.33 & 10.84 & 69.83 & 17.12 & 14.56 & 68.32 \\
\hline copepodites & $\mathrm{Va}$ & 2 & 18.91 & 9.92 & 71.17 & 16.10 & 14.35 & 69.55 \\
\hline adults & & 3 & $22.13 \pm 5.83$ & $12.84 \pm 7.29$ & $65.03 \pm 2.39$ & $20.25 \pm 5.65$ & $18.30 \pm 11.97$ & $61.45 \pm 6.63$ \\
\hline copepodites & 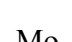 & 2 & 24.59 & 11.44 & 63.97 & 22.27 & 16.44 & 62.59 \\
\hline adults & Mo & 3 & $12.89 \pm 3.26$ & $25.95 \pm 4.55$ & $61.17 \pm 1.46$ & $11.60 \pm 3.17$ & $39.06 \pm 7.60$ & $49.34 \pm 4.52$ \\
\hline
\end{tabular}

quired for each analysis, could make a substantial contribution to reducing the uncertainty of proxy estimates. At present the use of stoichiometric models cannot be regarded as a substitute for direct biochemical analyses, although they have great potential as a powerful tool which only needs to be improved.

As regards the first question - the adequacy of the G\&B procedure for zooplankton proxy estimates - to evaluate the extent of the error which can result from neglecting chitin, the same zooplankton data were processed again using a modified set of equations with carbohydrate coefficients based on chitobiose stoichiometry (Vollenweider 2000, this issue).

The results emerging from the two calculation procedures are summarized in table 2 . The difference be- tween the two sets of estimates is substantial, involving a considerable increase in the carbohydrate fraction and a corresponding decrease in protein and, to a lesser extent, lipid fractions. The percent increase in carbohydrate fraction is on average $55 \%$ while the decrease in protein and lipid fractions is respectively 15 and $8 \%$.

If we take the proximate composition calculated according to Vollenweider's modified procedure as being more representative of the real zooplankton composition, the conclusions discussed in the earlier paper (Riccardi \& Mangoni 1999) need to be reviewed.

As for the observed seasonal variations in the biochemical composition of Daphnia hyalina and D. $\mathrm{cu}$ cullata, the conclusions which can be drawn from the new results are in general agreement with those result- 

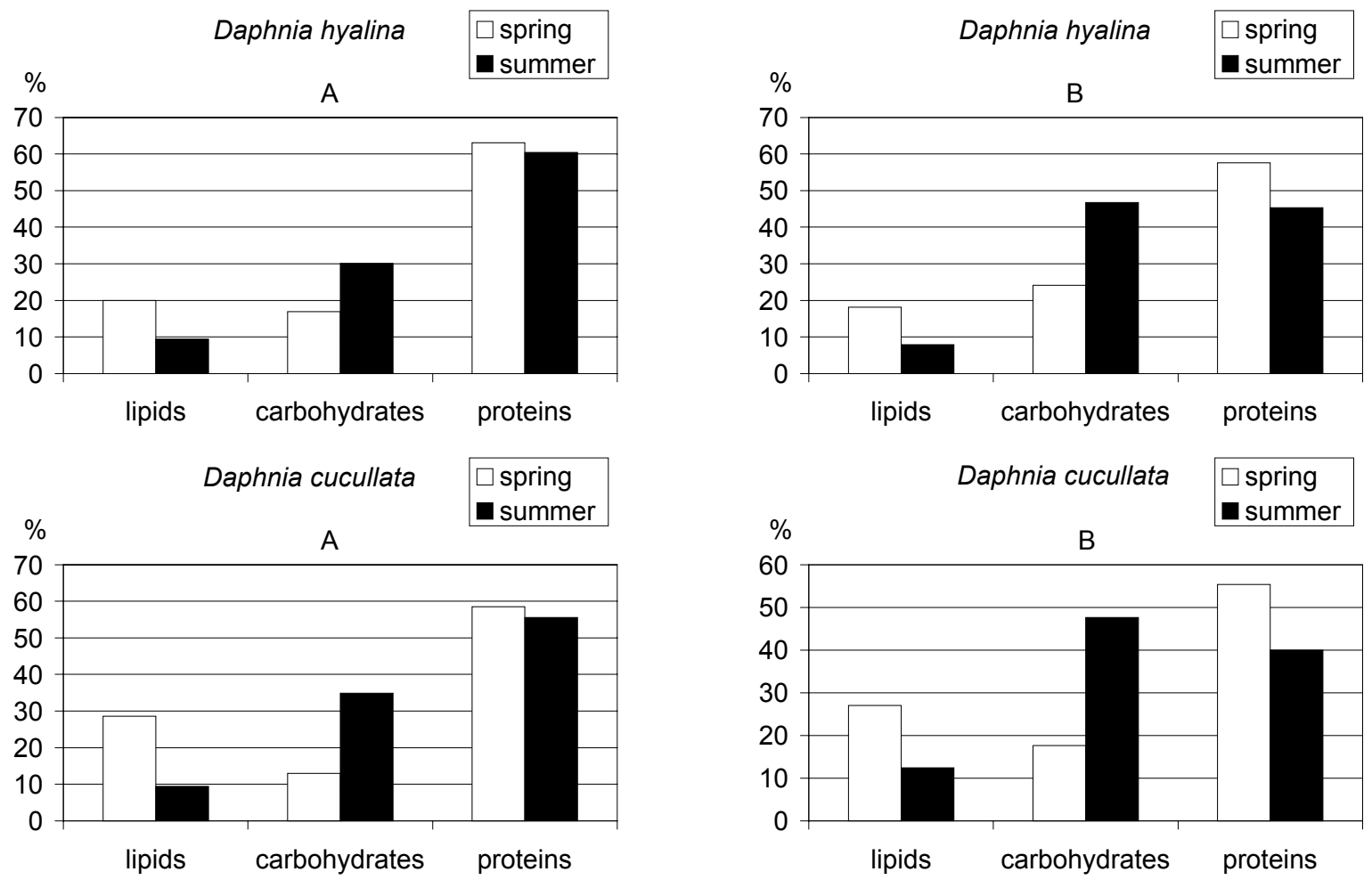

Fig. 1. Average proximate composition of Daphnia hyalina (Lake Monate) and D. cucullata (Lake Comabbio) in spring and summer calculated with Gnaiger \& Bitterlich's model (A) and Vollenweider's model (B).
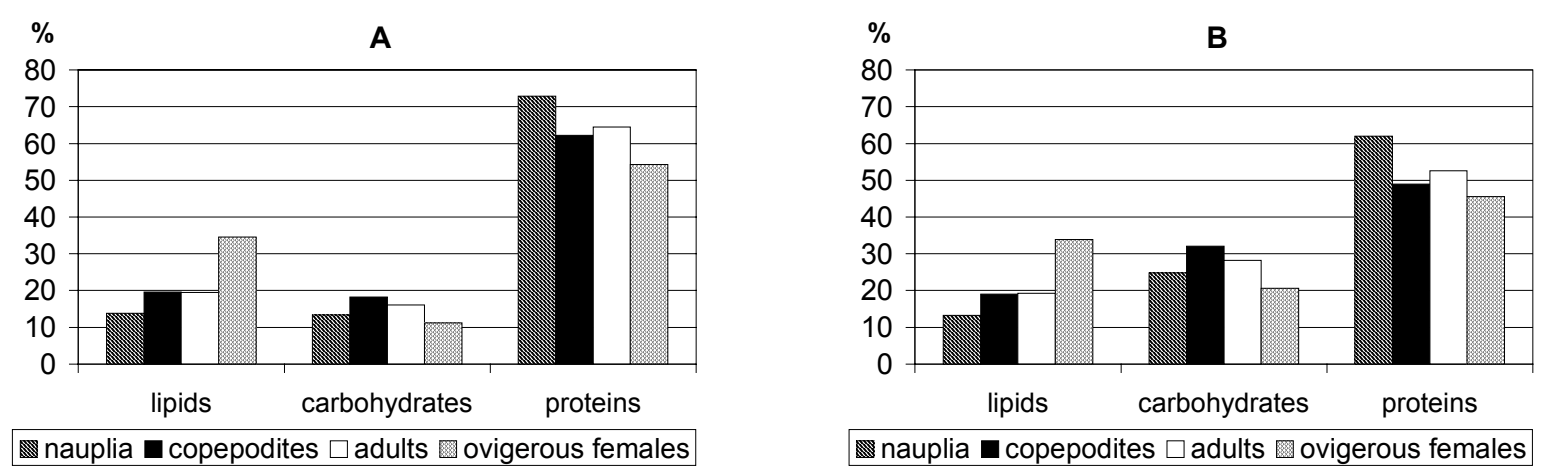

Fig. 2. Average proximate composition of Cyclops abyssorum developmental stages (Lake Comabbio) calculated with Gnaiger \& Bitterlich's model (A) and Vollenweider's model (B).

ing from the previous data. Indeed, as can be seen in figure 1 , the carbohydrate percentage increases from spring to summer while the lipid fraction drops by about $50 \%$. The major difference between the seasonal patterns resulting from the two calculation procedures is the decrease of proteins from spring to summer, which emerges only in Vollenweider's estimates. This difference is due to the allocation to the carbohydrates compartment of a nitrogen fraction which in Vollenweider's procedure is considered to be represented by chitin. Since the nitrogen percentage in Daphnia biomass does not vary from spring to summer, the summer increase of the carbohydrates fraction obviously results in a decrease of the protein fraction.

If we compare the composition of Cyclops abyssorum calculated by the two procedures (Fig. 2), the pattern of variation between the different developmental stages is similar, although the relative proportion of carbohydrates, lipids and proteins in all the considered stages is different. Ovigerous females have the highest lipid content and the lowest carbohydrate content.

Although measurement uncertainties can substantially affect proxi-composition estimates, particularly carbohydrates, the calculation of caloric content is 
Tab. 3. Total caloric content ( $\mathrm{kcal} \mathrm{g}^{-1}$ dry weight) of zooplankton species calculated according to Gnaiger \& Bitterlich's (1984) and the Vollenwider's (2000) procedures and available energy content ( $\mathrm{kcal} \mathrm{g}^{-1}$ dry weight) calculated by the energy conversion physiological coefficients $\left(4.2,8.0\right.$ and $1.6 \mathrm{kcal} \mathrm{g}^{-1}$ of protein, lipid and carbohydrate respectively). Lakes: $\mathrm{Co}=$ Comabbio; $\mathrm{Ma}=$ Maggiore; $\mathrm{Mo}=$ Monate and $\mathrm{Va}=$ Varese. No. $=$ number of samples.

\begin{tabular}{|c|c|c|c|c|c|c|}
\hline \multirow[t]{2}{*}{ Species } & \multirow[t]{2}{*}{ lake } & \multirow[t]{2}{*}{ No. } & \multicolumn{2}{|c|}{ Total caloric content } & \multicolumn{2}{|c|}{ Usable caloric content } \\
\hline & & & G\&B & $\mathrm{V}$ & G\&B & $\mathrm{V}$ \\
\hline \multirow[t]{2}{*}{ Daphnia cucullata } & $\mathrm{Co}$ & 11 & $5.17 \pm 0.75$ & $5.05 \pm 0.84$ & $3.63 \pm 0.87$ & $3.62 \pm 0.92$ \\
\hline & $\mathrm{Va}$ & 4 & $5.41 \pm 0.26$ & $5.37 \pm 0.37$ & $4.02 \pm 0.38$ & $3.99 \pm 0.50$ \\
\hline \multirow[t]{2}{*}{ Daphnia hyalina } & Mo & 8 & $4.93 \pm 0.30$ & $4.84 \pm 0.33$ & $3.49 \pm 0.34$ & $3.30 \pm 0.44$ \\
\hline & Ma & 2 & 4.75 & 4.75 & 3.42 & 3.24 \\
\hline Ceriodaphnia quadrangula & Co & 1 & 4.91 & 4.57 & 3.04 & 2.61 \\
\hline Bythotrephes longimanus & $\mathrm{Ma}$ & 1 & 5.24 & 5.19 & 3.75 & 3.59 \\
\hline Eudiaptomus padanus & Co & 7 & $5.64 \pm 0.66$ & $5.58 \pm 0.59$ & $4.25 \pm 0.60$ & $3.93 \pm 0.63$ \\
\hline \multirow[t]{2}{*}{ (adults + copepodites) } & Mo & 4 & $5.44 \pm 0.14$ & $5.17 \pm 0.14$ & $3.70 \pm 0.18$ & $3.44 \pm 0.26$ \\
\hline & $\mathrm{Ma}$ & 2 & 5.35 & 5.30 & 3.87 & 3.74 \\
\hline Cyclops abyssorum & & 6 & $5.22 \pm 0.25$ & $5.14 \pm 0.36$ & $3.78 \pm 0.38$ & $3.69 \pm 0.53$ \\
\hline copepodites & & 2 & 5.49 & 5.34 & 3.97 & 3.78 \\
\hline adults & $\mathrm{CO}$ & 5 & $5.39 \pm 0.24$ & $5.16 \pm 0.28$ & $3.57 \pm 0.36$ & $3.73 \pm 0.31$ \\
\hline ovigerous females & & 2 & 6.23 & 6.15 & 4.79 & 4.69 \\
\hline nauplia & & 1 & 5.39 & 5.47 & 4.08 & 4.11 \\
\hline copepodites & $\mathrm{Va}$ & 2 & 5.09 & 5.33 & 4.01 & 4.00 \\
\hline adults & & 3 & $5.61 \pm 0.27$ & $5.61 \pm 0.27$ & $4.21 \pm 0.38$ & $4.20 \pm 0.49$ \\
\hline copepodites & & 2 & 5.40 & 5.51 & 4.19 & 4.16 \\
\hline adults & Mo & 3 & $5.12 \pm 0.11$ & $4.83 \pm 0.13$ & $3.43 \pm 0.16$ & $3.24 \pm 0.23$ \\
\hline
\end{tabular}

rather insensitive to such variabilities (Gnaiger \& Bitterlich 1985; Vollenweider 2000).

The total caloric content was calculated on the proximate biochemical composition obtained by Vollenweider's procedure by multiplying the protein, carbohydrate and lipid concentrations by the relative caloric coefficients (i.e. 5.5 for proteins, 4.1 for carbohydrates and 9.3 for lipids). These caloric values are similar to those calculated according to Gnaiger \& Bitterlich's equation based on carbon concentration (Tab. 3). At this point, however, we must remember that the total caloric value indicates the amount of energy stored, for example, in an organism, but does not give any idea of the actual amount of energy potentially available to consumers. More interesting from a practical point of view is the estimation of the "usable" caloric content (or "exergy"), i.e. the amount of energy which can be transferred to the higher trophic levels. When considering the trophic linkage between zooplankton and planktivorous fish, a more realistic estimation of potential energy transfer could be made by using appropriate caloric coefficients for each dietary component.

Fish metabolism is mainly based on protein and lipid utilization, while dietary carbohydrates are poorly utilized, both at the level of digestion and of the capacity to metabolize absorbed carbohydrates (e.g. Brett \& Groves 1979; Moyle \& Cech 1982). Using average digestibility values for each dietary component and adjusting the protein for its nitrogen content (nitrogen is unavailable for energy), Phillips \& Brockway (1959) determined the physiological values for trout to be $3.9 \mathrm{kcal} \mathrm{g}^{-1}$ of pro- tein, $8.0 \mathrm{kcal} \mathrm{g}^{-1}$ of fat, and $1.6 \mathrm{kcal} \mathrm{g}^{-1}$ of carbohydrate. The value of $3.9 \mathrm{kcal}$ "available" energy $\mathrm{g}^{-1}$ of protein was arrived at by applying an average digestibility factor of 0.9 and deducting $1.3 \mathrm{kcal} \mathrm{g}^{-1}$ from the gross energy of digestible protein $\left(5.66 \mathrm{kcal} \mathrm{g}^{-1}\right)$. The deducted value of $1.3 \mathrm{kcal} \mathrm{g}^{-1}$ corresponds to the heat of combustion and biosynthesis of nitrogenous excretory products (urea, uric acid and creatinine). Since freshwater teleost fish excrete primarily ammonia, the nonmetabolizable energy fraction of absorbed dietary protein should reflect the heat of combustion of ammonia, that is 0.95 $\mathrm{kcal} \mathrm{g}^{-1}$ of protein (Elliott \& Davison 1975). Therefore, according to Brett \& Groves (1979) the energy available to freshwater fish in dietary protein is approximately 4.2 $\mathrm{kcal} \mathrm{g}^{-1}$ rather than $3.9 \mathrm{kcal} \mathrm{g}^{-1}$. The value of $1.6 \mathrm{kcal} \mathrm{g}^{-1}$ of dietary carbohydrate proposed by Phillips \& Brockway (1959) also appears questionable, at least when considering planktivorous fish, since it was obtained by applying the mean digestibility factor of raw starch, which probably does not apply to the carbohydrate fraction of zooplankton. If we assume that chitin represents the main carbohydrate fraction of zooplankton, the amount of usable energy should probably be lower than Phillips and Brockway's value. In fact, although chitinolytic activity has been observed in the digestive tract of several fish species (e.g. Yoshida \& Sera 1970; Sakata et al. 1980; Benmouna et al. 1986; Seiderer et al. 1987; Danulat 1987), it is not clear how far chitin is effectively assimilated and utilized for metabolic requirements. Indeed, several authors have observed chitinous exoskeletons lingering in the gut of fish (e.g. Mann 
Tab. 4. Comparison between total caloric content of zooplankton species and percentage of usable energy estimated by proxicomposition (this research) and measured caloric content and energy utilization by fish (Giussani \& de Bernardi 1977). Caloric values are expressed as $\mathrm{kcal} \mathrm{g}^{-1}$ ash free dry weight.

\begin{tabular}{|c|c|c|c|c|c|c|c|}
\hline & \multicolumn{2}{|c|}{ Giussani \& de Bernardi 1977} & \multicolumn{5}{|c|}{ This research } \\
\hline & \multirow[b]{2}{*}{$\begin{array}{c}\text { total } \\
\text { caloric content }\end{array}$} & \multirow[b]{2}{*}{$\begin{array}{c}\% \\
\text { utilization }\end{array}$} & \multirow[b]{2}{*}{$\begin{array}{c}\text { total } \\
\text { caloric content }\end{array}$} & \multicolumn{2}{|c|}{ A } & \multicolumn{2}{|l|}{ B } \\
\hline & & & & $\begin{array}{c}\text { usable } \\
\text { caloric content }\end{array}$ & $\begin{array}{c}\% \text { usable } \\
\text { energy }\end{array}$ & $\begin{array}{c}\text { usable } \\
\text { caloric content }\end{array}$ & $\begin{array}{c}\% \text { usable } \\
\text { energy }\end{array}$ \\
\hline Daphnia hyalina & 5.552 & 74.3 & 5.480 & 3.738 & 68.0 & 3.170 & 57.4 \\
\hline Bythotrephes longimanus & 5.983 & 44.7 & 5.500 & 3.799 & 69.1 & 3.264 & 59.3 \\
\hline Cyclops abyssorum & 5.905 & 72.7 & 5.786 & 4.176 & 71.9 & 3.761 & 64.5 \\
\hline Eudiaptomus padanus & 6.484 & 0 & 5.724 & 3.694 & 70.0 & 3.352 & 58.1 \\
\hline
\end{tabular}

1948; Gerking 1952; Kionka \& Windell 1972), and others reported a reduction of growth in fish fed with increasing levels of chitin and chitosan in the diet (e.g. Shiau \& Yu 1999). Moreover, being considered almost undigestible, chitin has been suggested as a suitable marker for use in digestibility studies (e.g. Buddington 1980; Jobling 1993).

By applying the above mentioned physiological coefficients $\left(4.2,8.0\right.$ and $1.6 \mathrm{kcal} \mathrm{g}^{-1}$ of protein, lipid and carbohydrate respectively) to the proximate composition of each zooplankton species we obtained an estimate of the available energy content (Tab. 3), which amounts to about 57 to $76 \%$ of the total caloric value. These percentages would fall to approximately 36 to $71 \%$ if the carbohydrate fraction in zooplankton were completely made up of undigestible chitin.

The utilization of energy by the most important pelagic zooplanktophagous fish of Lago Maggiore, Coregonus sp., was estimated by Giussani \& de Bernardi (1977), who measured by direct calorimetry the amount of energy in the fish prey, in the stomach content and in the feces excreted. Their results are, surprisingly, in very good agreement with the values calculated from proximate composition (Tab. 4), with the exception of two species, Eudiaptomus padanus and Bythotrephes longimanus. For the first species the difference arises from the fact that Eudiaptomus padanus, in common with other calanoid copepods, is not preyed on by whitefish even in lakes where calanoids are the commonest crustaceans (e.g. Giussani 1974; Lazzaro 1987; Mookerji et al. 1998). Therefore, the potentially available energy stored in calanoid species is not utilized by fish. Conversely, Bythotrephes longimanus, which is generally rare in plankton, is strongly preferred by whitefish in many lakes (e.g. Giussani 1974; Becker \& Eckmann 1992; Mookerji et al. 1998; Coulas et al. 1998) but, as Giussani \& de Bernardi (1977) pointed out, the utilization of the energy content of this species is surprisingly low (about 45\%), in spite of the fact that with its low density the energy cost to the predator of searching could be high. To explain the difference between the measured energy utilization and the usable energy content calculated for this species we can hypothesize that it may be less digestible because of its large size, since fish digestion rates are related to surface to volume ratio (Jobling 1987). According to Giussani (personal communication) the extent of food energy utilization by whitefish seems to vary over time with variations in the physiological conditions of the fish. Prey dominance in the stomach of Coregonus shifts from Daphnia to Bythotrephes in August when the fish has finished accumulating perivisceral fat for gonad development and its growth rate is substantially reduced. Therefore, the low utilization of food energy (in this case Bythotrephes) could be due to the reduced metabolic requirements of the fish in this season.

A comparison of the data on the other two species (Daphnia hyalina and Cyclops abyssorum) with the caloric values calculated on proximate composition shows that there is better agreement when carbohydrate energy content is included (column A in Tab. 4), while the exclusion of carbohydrates gives less consistent results (column B, Tab. 4). This suggests two possibilities: a) either chitin does not account for total zooplankton carbohydrates, or b) chitin can be digested and assimilated by planktivorous fish with an efficiency similar to that measured for other complex carbohydrates (i.e. raw starch).

In summary we can conclude that:

- A thorough examination of the mathematical procedure for calculating proxi-composition from $\mathrm{CHN}$ data (Vollenweider 2000, this issue) has highlighted the weaknesses of indirect estimates, which cannot be regarded as an alternative tool on a par with direct biochemical analyses. However, direct biochemical analyses are also affected by a large degree of uncertainty (e.g. Madin et al. 1981; Zamer et al. 1989) and in many cases the sum of direct estimates of the different components (proteins, lipids and carbohydrates) does not account for the total organic mass of the sample (e.g. Conover 1978; Madin et al. 1981). Comparisons between direct and stoichiometric estimates on standard reference material and biological samples of different kinds could help to decide which approach leads to more dependable and viable results, and what degree of uncertainty we should expect to be introduced into our results when using each of the alternative approaches. 
- The recalculation of zooplankton proximate composition using chitobiose stoichiometric coefficients to compute the carbohydrate fraction results in a considerable increase of carbohydrate and a decrease of protein fraction.

- Whatever model is used for calculation, the pattern of variation among different seasons or developmental stages is similar: Daphnia stores more lipids in spring than in summer, when the decrease of lipids is offset by an increase in carbohydrates. If carbohydrates were represented by chitin alone, the summer increase would suggest the deposition of a thicker exuvia; conversely, if glycogen is also present, the summer increase could indicate a metabolic shift from the use of lipids to that of carbohydrates as an energy source. The proximate composition of Cyclops abyssorum changes according the stage of development: nauplius has the highest protein content, which probably indicates an active biosynthesis of new biomass; ovigerous females attain the highest lipid content, which probably accounts for the energy reserves stored in eggs, while the low percentage of protein could indicate that biomass synthesis stops when maturity is reached.

- In spite of the differences in proximate composition resulting from the two calculation procedures, the total caloric content is similar.

- To obtain more useful information on potential energy transfer to the higher trophic level, the "usable" caloric content can be estimated from proximate composition. The agreement between the measured values of actual energy utilization by planktophagous fish and the calculated available energy content of preys supports the consistency of these estimates.

- The theoretical approach to proximate composition and "usable" energy estimates would be improved by parallel biochemical analysis of zooplankton biomass and, particularly, by determination of exuvia components. Moreover, an analysis of the variations in the biochemical composition of plankton produced by fish digestion could produce very interesting results in evaluating not only the quantity of energy lost with feces, but also the assimilation coefficients for the different biochemical fractions.

\section{Acknowledgments}

I am very grateful to Dr. R.A. Vollenweider for the extremely fruitful discussion which gave rise to this manuscript and for his constructive criticism on an earlier draft. I also wish to thank my colleagues who contributed to the improvement of this paper with information and suggestions: Roberto Bertoni, Gianluigi Giussani and Oscar Ravera (Istituto Italiano di Idrobiologia) and Ettore Grimaldi (University of Milan). Many thanks are due to Dr. Sandra Spence for the English revision.

\section{REFERENCES}

Becker, M. \& R. Eckmann. 1992. Plankton selection by pelagic European whitefish in Lake Constance: dependecy on season and time of day. Pol. Arch. Hydrobiol., 39: 393402.

Benmouna, H., M.F. Jaspar-Versali, C. Toussaint \& Ch. Jeuniaux. 1986. A comparative study of chitinase in digestive tract of Serranus cabrilla and Serranus scriba. Biochem. Syst. Ecol., 14: 435-437.

Brett, J. R. \& T.D.D. Groves. 1979. Physiological energetics. in: W.S. Hoar, D.J. Randall \& J.R. Brett (Eds), Fish physiology. Vol. VIII. Bioenergetics and growth. Academic Press, New York, USA : 279-352.

Buddington, R.K. 1980. Hydrolysis-resistant organic matter as a reference for measurement of fish digestive efficiency. Trans. am. Fish. Soc., 106: 635-656.

Coulas, R.A., H.J. MacIsaac \& W. Dunlop. 1998. Selective predation on an introduced zooplankter (Bythotrephes cederstroemi) by lake herring (Coregonus artedii) in Harp Lake, Ontario. Freshwat. Biol., 40: 343-355.

Danulat, E. 1987. Digestibility of chitin in cod, Gadus morhua, in vivo. Helgol. Meeresunters., 41: 425-436.

Elliott, J.M. \& W. Davison. 1975. Energy equivalents of oxygen consumption in animal energetics. Oecologia, 19: 195-201.

Gerking, S.D. 1952. The protein metabolism of sunfishes of different ages. Physiol. Zool., 25: 358-372.

Giussani, G. \& R. de Bernardi. 1977. Food selectivity in Coregonus sp. of Lago Maggiore: an energetical approach. Mem. Ist. ital. Idrobiol., 34: 121-130.

Giussani, G. 1974. Planctofagia selettiva del coregone "bondella" (Coregonus sp.) del Lago Maggiore. Mem. Ist. ital. Idrobiol., 31: 181-203.

Gnaiger, E. \& G. Bitterlich. 1984. Proximate biochemical composition and caloric content calculated from elemental CHN analysis: a stoichiometric concept. Oecologia, 62: 289-298.

Gnaiger, E. \& G. Bitterlich. 1985. CHN stoichiometric analysis. Cyclobios Newsletter, No. 2, Apr 1985.

Jobling, M. 1987. Influences of food particle size and dietary energy content on pattern of gastric evacuation in fish: test of a physiological model of gastric emptying. J. Fish Biol., 30: 299-314.

Jobling, M. 1993. Bioenergetics: feed intake and energy partitioning. in: J.C. Rankin \& F.B. Jensen (Eds), Fish ecophysiology. Chapman \& Hall, London, U.K. : 1-44.

Kionka, B. C. \& J. T. Windell. 1972. Differential movement of digestible and indigestible food fractions in rainbow trout, Salmo gairdneri. Trans. am. Fish. Soc., 101: 112115.

Lazzaro, X. 1987. A review of planktivorous fishes: their evolution, feeding behaviours, selectivities and impacts. Hydrobiologia, 146: 97-167.

Madin, L.P., C.M. Cetta \& V.L. McAlister. 1981. Elemental and biochemical composition of salps (Tunicata: Thaliacea). Mar. Biol. 63: 217-226.

Mann, V.H. 1948. Über die Rohfaser-Verdauung des Karfens. Arch. F. Fisch., 1: 1-11.

Mookerji, N., C. Heller, H.J. Meng, H.R. Bürgi \& R. Müller. 1998. Diel and seasonal patterns of food intake and prey selection by Coregonus sp. in re-oligotrophicated Lake Lucerne, Switzerland. J. Fish Biol., 52: 443-457.

Moyle P.B. \& J.J. Cech, jr. 1982. Fishes: an introduction to ichthyology. Prentice Hall, Englewood, Cliffs, New Jersey: $543 \mathrm{pp}$

Phillips, A.M. Jr. \& D.R. Brockway. 1959. Dietary calories and the production of trout in hatcheries: Progr. Fish. Cult., 21: 3-16.

Riccardi, N. \& M. Mangoni. 1999. Considerations on the biochemical composition of some freshwater zooplankton species. J. Limnol., 58: 58-65.

Sakata, T., Okabayashi, J. \& D. Kakimoto. 1980. Variations in the intestinal microflora of Tilapia reared in fresh and sea water. Bull. Jap. Soc. Sci. Fish. Nissuishi., 46: 313-317. 
Seiderer, L.J., C.L. Davis, F.T. Robb \& R.C. Newell. 1987. Digestive enzymes of the anchovy Engraulis capensis in relation to diet. Mar. Ecol. Prog. Ser., 35: 15-23.

Shiau, S.Y. \& Y.P. Yu. 1999. Dietary supplementation of chitin and chitosan depresses growth in tilapia, Oreochromis niloticus x O. aureus. Aquaculture, 179: 439-446.

Vollenweider, R.A. 2000. Concerning calculation methods and limitations of proxi-estimates of proteins, carbohydrates and lipids in crustacean zooplankton from $\mathrm{CHN}$ analyses: some comments. J. Limnol., 59(2): 170-178.
Yoshida, Y. \& H. Sera. 1970. On chitinolytic activities in the digestive tracts of several species of fishes and the mastication and digestion of foods by them. Bull. Jap. Soc. scient. Fish., 36: 751-754.

Zamer, W.E., J.M. Shick \& D.W. Tapley. 1989. Protein measurement and energetic considerations: comparison of biochemical and stoichiometric methods using bovine serum albumin and protein isolated from sea anemones. Limnol. Oceanogr., 34: 256-263. 